\title{
Design and Development of Pedal Operated Maize Sheller for Small and Marginal Farmers
}

\author{
R. Prajwal*, V. Tanveer Mujtabha, V.N. Meghana and Er. Prasanna Kumar
}

College of Agricultural Engineering, GKVK, UAS - Bengaluru, 560065, Karnataka, India

*Corresponding author

\section{A B S T R A C T}

Keywords

Pedal operated,

Maize sheller,

Tubular maize

shelling, Shelling

efficiency

Article Info

Accepted:

12 December 2020

Available Online:

10 January 2021
In India, Maize (Zea mays) is an important crop after the rice and wheat. Many farmers grow maize but could not afford the cost of acquiring some of the imported threshing machines because of their cost. Such people resort to manual means of threshing which results into low efficiency, high level of wastage and exerting of much labor. This machine was constructed to shell maize and separate the cob from the grains. It was constructed from locally available materials and its cost is low and affordable. The operating speed of pedal operated maize sheller was optimized for its operation at higher or lower operating speeds in pedaling mode. The performance of the pedal operated maize sheller was evaluated with local or traditional shelling method - tubular maize shelling. The capacity of machine was $58-62 \mathrm{~kg} / \mathrm{hr}$ which is 3 to 4 times than tubular maize shelling and with maximum shelling efficiency and cleaned outlet grain i.e. $98 \%$ and minimum mechanically damaged i.e. less than $2 \%$ at moisture content of maize was $10 \%$. The pedal operated maize sheller can be effectively used by the farmers for shelling of maize.

\section{Introduction}

Maize (Zea mays) is one of the most common cereal grain grown in the world. It belongs to a grass family (Gramineae) and originated from Mexico and South America. The plant prefers light (sandy), medium (loamy), and heavy (clay) soils and requires well-drained soil. It cannot grow in the shade and also requires moist soils. The period between planting and harvesting for maize depend upon the variety, but in general the crop physiologically mature in 7 to 8 weeks after flowering, at that time the kernel contains 35 to $40 \%$ moisture and has the maximum content of dry matter. Maize shelling is difficult at moisture content above $25 \%$, with this moisture content, grain stripping efficiency is very poor with high operational energy and causing mechanical damage to the 
seed. A more efficient shelling is achieved when the grain has been suitably dry to 13 to 14\% moisture content. (Danilo, 1991)

Shelling is the removal or separation of maize grain from the cob and it is an operation that follows the harvest. It can be carried out in the field or on the farm by hand or machines. The grain is obtained by shelling, friction or by shaking the products. The difficulty of the operation depends on the varieties grown, the moisture content and the degree of maturity of the crop.

Maize is shelled traditionally by hands. This is done in such a way that maize is rubbed against another until the grains are removed from the cob. Likewise the grain can be detached from the cob with the use of pestle and mortal. But this traditional method of shelling is highly tedious, inefficient and time consuming with low productivity (FAO, 2005). However, the modern way of shelling is by the use of mechanical means, which can be driven by prime mover or tractor. This prime mover can either be diesel/petrol engine or electric motor.

The efficiency and throughput of this machine depending on the type of machine, the skill of workers and organization of the work, yield can vary from 100 to $5000 \mathrm{~kg} / \mathrm{h}$ (FAO, 2005). The power requirement of such sheller is high and hence, the prime mover is very expensive. Hence, a pedal operated maize sheller is simple in design, affordable and suitable for small and marginal farmers and will meet the need of the farmers for growing maize.

Keeping in view the above facts, the present study has been has been undertaken by following objectives. It was proposed to design a pedal operated maize sheller with following objectives include to design and develop pedal operated maize sheller. And also to evaluate the performance of the maize sheller.

\section{Materials and Methods}

This section includes the materials used and the methods and procedures that were adopted during the study.

\section{Idea generation}

India is the third largest producer of maize and due to the increased in demands of its processed form (preserve) both in national and international markets, shelling is considered as a major economic activity for the individuals associated with it.

In developing countries like India there is always a problem of availability of resources and power especially in the rural areas. The supply of electricity is not uniform and fossil fuels are not always an option when farmer wants to keep the operating costs of a operational low in order to increase the profits. Also, rural women are among the least privileged, not only do women perform agricultural duties and care for livestock alongside men, but women are also responsible for many domestic chores.

Usually, new technology improves people's efficiency, but women benefit less from new technology for several reasons. There are existing solutions and machines were developed in the past that runs on manual power but the capacity and quality of shelling was poor. Also the maize need to be graded so that they can fit in these machines and the effort required was more leading to repetitive strain injuries during a longer span of time due to the postural discomfort.

So, the idea was to design and develop a gender equal machine which can eliminate the need of size grading and can run on manual energy with a little effort and more capacity. The steps that was followed for 
designing and development operational of the machine is as follows:

\section{Sketch and preliminary design}

\section{Selection of materials}

Various materials that were used in the fabrication of the machine are as follows.

\section{Frame structure}

This forms the main skeleton of the machine. It was made strong enough to resist the maximum magnitudes of compressive, tensile and impact forces i.e, $250 \mathrm{MPa}, 370 \mathrm{MPa}$ and $2000 \mathrm{MPa}$ respectively and simultaneously support the other parts of the machine fixed on it.

\section{Shelling unit}

The shelling unit was fixed on the right side of the machine. It consists of cast iron sheller for shelling and the teeth are tapered.

\section{Transmission system}

It includes the various components which were employed to transmit the power from the lower back and leg muscles of the worker finally to the shelling unit with the help of shafts, chains and sprockets and plumber block.

\section{Plummer block}

A Plummer block or bearing housing is a pedestal used to provide support for a rotating shaft with the help of compatible bearings \& various accessories. Housing material for a plummer block is typically made of cast iron or cast steel.

\section{Miscellaneous materials}

There were many items which have not been mentioned under any subheading. These were nuts and bolts, steel screws, pedals, seat, shelling unit and welding kit (iron and steel) with welding rods.

\section{Performance parameters of machine}

After the machine was made, the testing of the machine was done considering the following parameters:

Independent/Operational parameters:

Moisture Content (\%)

Feed rate $(\mathrm{kg} / \mathrm{h})$

Dependent/Response parameters:

Machine capacity $(\mathrm{kg} / \mathrm{h})$

Unshelled grain (\%)

Mechanically damaged grain (\%)

Shelling efficiency (\%)

Cleaned outlet grain $(\%)$

\section{Capacity of machine}

The shelling capacity was determined as the weight of cobs shelled in an hour, and expressed as $\mathrm{kg}$ of $\mathrm{cob} / \mathrm{h}$.

\section{Unshelled grain}

Unshelled grain is defined as the amount of unshelled grain (maize) remains at the cob after the shelling operation.

\section{Mechanically damaged grain}

Mechanically damaged grain (maize) is defined as grain which is damaged by machine during shelling operation. To determine the percentage of grain damage with weight the split and cracked grains are weighted (Metwally, 2010):

$\mathrm{P}_{\mathrm{GD}}=\frac{\mathrm{W}_{\mathrm{sg}}}{\mathrm{Ws}_{s}} \times 100$, 
where: $\mathrm{P}_{\mathrm{GD}}$ is the grain damage $(\%)$, Wsg is the weight of split grains $(\mathrm{g})$, and $\mathrm{W}_{\mathrm{S}}$ is the weight of corn sample used $(\mathrm{g})$.

\section{Shelling efficiency}

Shelling efficiency is defined as the mass of the kernels actually shelled to the total mass of kernels on the ear before shelling.

Shelling efficiency $=$

$\frac{\text { mass of the kernels actually shelled }}{\text { total mass of kernels on the ear before shelling }}$

\section{Cleaned outlet grain}

Cleaned outlet grain is defined as the quantity of maize clean has no damage and unwanted materials.

Total grain output $=$ Cleaned grain + damaged grain

\section{Moisture determination of maize}

\section{Procedure}

- Set the oven to pre heat to the required temperature $\left(130^{\circ} \mathrm{C}\right)$

- Weight empty container along with lid

- Put the working sample to the weighed container in duplicate and weigh again before drying

- Weighing should be up 3 decimal

- Remove the lead and place then underneath the container and place in to oven at appropriate temp. And for a required period.

- Switch off the oven at the end of drying period and transfer to desiccators to cool for 30- $45 \mathrm{~min}$

- After cooling weigh the containers with its lid and contents

Moisture content determination:

MC $(\%)=\{$ loss in weight $/$ weight of working sample\} x 100

\section{Results and Discussion}

To address the problem of shortage of electricity in rural and semi urban areas, manual implement is required. So, a pedal operated maize shelling machine was developed which would be easy to operate and require low maintenance and simultaneously overcome the problems of food safety and hygiene.

\section{Preliminary sketch and design diagram}

A preliminary sketch was prepared before the actual designing of the machine to work out the plan.

\section{Detailed description of working of pedal operated maize shelling machine}

The energy required for the pedaling activity in order to run the machine came from the legs, lower back, abdomen and thigh muscles. The person remained seated on the seat and started the pedaling activity with the help of pedals made up of plastic. A specially designed seat made up of rubber was provided on the machine itself for the user so that he/she could balance his/her body properly during the activity.

The energy from the pedals was transmitted with the help of chain and sprockets made up of cast iron. Iron chain was used as the pedal chain, laid on the sprockets at the pedal end and at the main shaft in the horizontal direction. A shelling unit was fitted at the end of this shaft. The feed i.e. maize was provided with the help of hand into the shelling unit. As the person started pedaling activity, the pedal side chain and sprocket drive the main shaft with the help of bearings and in turn the shelling unit and starts revolving. The maize cobs come in contact 
with the teeth of the shelling unit and shelled out from the cob. The shelled maize were then collected at the outlet.

\section{Principle of operation}

The transmission system provides the primary motion required to run the machine. The motion and torque are transmitted via chain, sprocket and bearings to the shaft attached to the sheller which has shelling teeth. The maize (together with the cobs) is introduced into the machine by hand into the shelling unit. They reach the rotating sheller inside the de-cobing teeth by action of sheller. The teeth gave continuous impact force on the whole maize, thereby removing the grains. Because the teeths are given slope 1:2(out to in), the whole maize moves along the length of the sheller in the forward direction until they reach the cob exit. Before the whole maize reaches this point, almost all the grains (seeds) was removed.

Due to the impact of the teeth some of the cobs may be broken, though both broken and whole exit through the exit spout. The clean maize then run into the receiver where they are collected for further processing operations.

\section{Consideration of manufacturing operational}

The points which were considered for the manufacturing operational were the availability of raw material and feasibility of manufacturing operations.

\section{Sheller}

Sheller was the part of shelling unit and its function was shelling of maize.

\section{Chain and sprockets}

Chains and sprockets were used for the transmission of power. One set of chain and sprockets was used at the pedal side and to connect the main shaft.

\section{Floor space requirement}

The floor space requirement of the machine for working and storage was $4800 \mathrm{~cm}^{2}$ [120 $\mathrm{cm}(\mathrm{L}) \times 40 \mathrm{~cm}(\mathrm{~B})]$.

\section{Experimental results}

$\begin{array}{lc}\text { Weight of } 1 \text { cob (average) } & 167 \mathrm{~g} \\ \begin{array}{l}\text { Feed } \\ \text { Shelled grain (average) }\end{array} & 58.86 \mathrm{Kg} \\ \begin{array}{l}\text { Unshelled grain and } \\ \text { Damaged grain (average) }\end{array} & 1.13 \mathrm{Kg} \\ \begin{array}{l}\text { Time consumed for } \\ \text { shelling of 1 cob (average) }\end{array} & 9 \mathrm{sec} \\ \begin{array}{l}\text { Time consumed for } \\ \text { changing of Maize cob(average) }\end{array} & 2 \mathrm{sec} \\ \text { Shelling efficiency } & 98.10 \%\end{array}$

\section{Calculation of machine capacity}

Time consumed for shelling of $1 \mathrm{cob}$ (average) $=9 \mathrm{sec}$

For 1 min maize/cob shelled $\quad=1.02 \mathrm{Kg}$

For 1 hr maize/cob

shelled $\quad=61.2 \mathrm{Kg}$

Therefore, Machine capacity $=58-62 \mathrm{Kg} / \mathrm{hr}$ The Machine capacity, by considering $1 / 3$ rd of the rest $\quad=348$ to $372 \mathrm{Kg} /$ day 
Table.1 Materials used for development of angle frame structure

\begin{tabular}{ccc}
\hline $\begin{array}{r}\text { Sr.No. } \\
\begin{array}{r}\text { Name of part } \\
\text { used }\end{array}\end{array}$ & Materials \\
1. & Frame structure & Mild steel \\
\hline
\end{tabular}

Table.2 Materials used for development of shelling unit

\begin{tabular}{clc}
\hline Sr.No. & Name of part & Materials used \\
1. & Sheller & Mild steel \\
2. & Shelling teeth & Mild steel \\
3. & Frame & Mild steel \\
\hline
\end{tabular}

Table.3 Materials used for development of transmission system

\begin{tabular}{lll}
\hline Sr.No. & Name of part & \multicolumn{1}{c}{ Materials used } \\
1. & Chains & Cast Iron \\
2. & Sprockets & Stainless steel \\
3. & Plummer Block & Cast iron \\
4. & Pedal & Rubber and SS \\
5. & Shafts & Mild steel \\
\hline
\end{tabular}

Table.4 Specification of plummer block

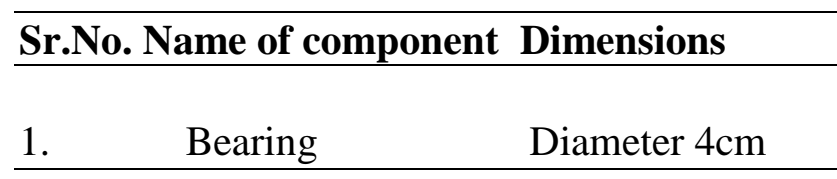

Table.5 Physical properties of maize cob

Parameters

Cob size, $\mathrm{cm}$

Average kernel moisture content at time of tests, \%

(db)

Average number of cobs in $20 \mathrm{~kg}$ sample

Kernel/pith ratio

Cob length

Maximum cob diameter at base end 
Table.6 Specifications of the model

\begin{tabular}{ll}
\hline Parameters & Size \\
\hline Shaft length & $34 \mathrm{~cm}$ \\
Shaft diameter & $2 \mathrm{~cm}$ \\
Bearings diameter & $4 \mathrm{~cm}$ \\
Length of the chain & $212 \mathrm{~cm}$ \\
Main shaft gear/sprocket teeth & 18 teeth \\
Pedal shaft gear teeth & $36 \mathrm{teeth}$ \\
Stand dimensions & $97 \mathrm{~cm} \mathrm{x} \mathrm{30cm}$ \\
Grain outlet box & $35 \mathrm{~cm}(\mathrm{~L}) \times 17 \mathrm{~cm}(\mathrm{~B}) \mathrm{x}$ \\
& $43 \mathrm{~cm}(\mathrm{a}) \times 53 \mathrm{~cm}(\mathrm{~b})$ \\
& \\
Shelling unit diameter & $8 \mathrm{~cm}$ \\
Shelling unit length & $14 \mathrm{~cm}$ \\
Length of the shelling teeth & $10 \mathrm{~cm}$ \\
Slope of shelling teeth & $1: 2(\mathrm{out}$ to in) \\
\hline
\end{tabular}

Table.7 Cost estimation of the model

\begin{tabular}{lc}
\hline Parameters & Cost (Rs.) \\
Angle iron and metal plate & 500 \\
Cycle frame & 500 \\
Bearings and shaft & 500 \\
Paint & 100 \\
Miscellaneous (Chain, seat, nut and bolt, & 400 \\
sprocket etc.) & \\
Total & $\mathbf{2 0 0 0}$ \\
\hline
\end{tabular}

Table.8 Experimental results

\begin{tabular}{lcccc}
\hline Trials & Feed(Kg) & Shelled grain $(+\mathbf{c o b}), \mathbf{K g}$ & $\begin{array}{c}\text { Unshelled grain } \\
\text { Damaged grain } \\
(\mathbf{K g})\end{array}$ & Shelling Efficiency(\%) \\
1. & 60 & 58.9 & 1.1 & 98.16 \\
2. & 60 & 59.2 & 0.8 & 98.66 \\
3. & 60 & 58.5 & 1.5 & 97.50 \\
\hline
\end{tabular}


Figure.1 Front view of pedal operated maize sheller

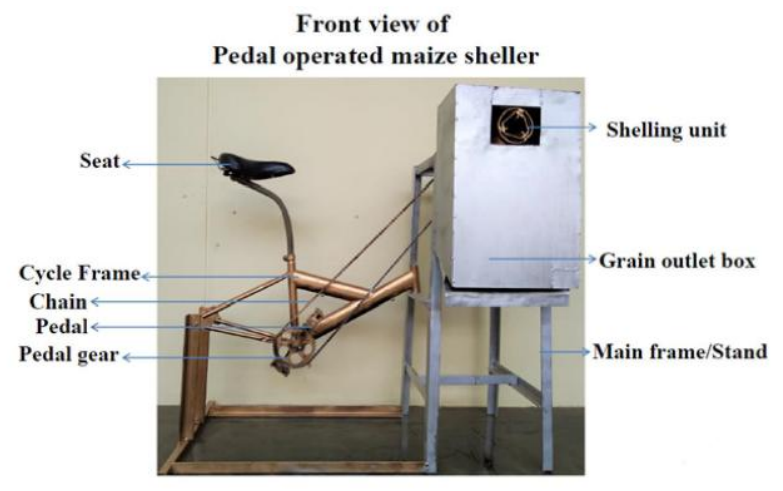

Figure.2 Side view of pedal operated maize sheller

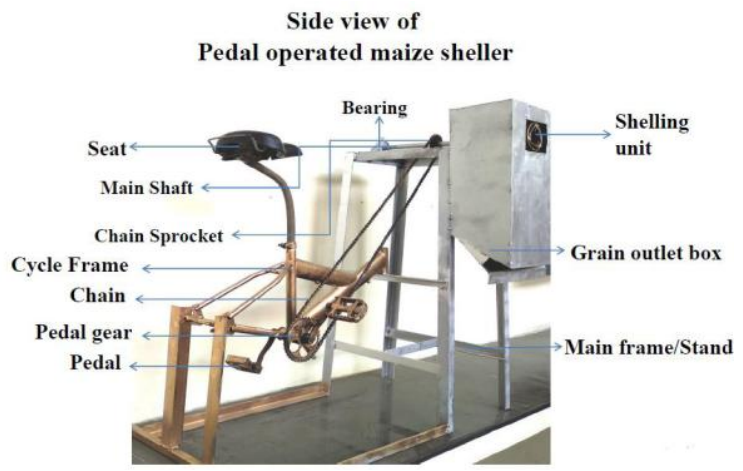

This chapter presents the discussion regarding the findings of the study. A pedal operated maize shelling machine was designed and developed. The machine was pedal operated and could be operated at various r.p.m manually. The capacity of machine varied from $58-62 \mathrm{~kg} / \mathrm{h}$ at $10 \%$ moisture content and at different speed of operation. The capacity of machine was maximum 348 - $372 \mathrm{~kg} /$ day considering $1 / 3$ rd of the rest given to farmer, with maximum shelling efficiency and cleaned outlet grain $98.10(\%)$ and minimum mechanically damaged and unshelled grain i.e. less than $1.88 \%$.

If the unshelled grain percentage increases, the shelling efficiency of the sheller gets decrease and if the damaged grain percentage increases, the grains will be much more susceptible to micro-organisms and fungal attacks, results in loss of grains during storage. One such study was taken by Sahil et $a l$., i.e., lowest grain damage percentage $(1.712 \%)$ was obtained at the moisture content of $16 \%$ and the highest grain damage percentage $(2.606 \%)$ was obtained at the moisture content of $20 \%$.

When grain moisture increased, it leads to adhesion of the grains to the cobs resulted in grain damage with beating inside the machine.

In conclusion, the traditional method of maize shelling creates much drudgery to the farmer, consumes more time for the shelling operation. Hence, the pedal operated maize sheller is simple in its design, cost effective and can be efficiently used by small and marginal farmers. Even unskilled labor can 
operate without any damage to their hands as the rpm of the shelling unit is controlled manually. As no power source is used, the sheller can be used in the field, yards or at the farm house. The pedal operated maize sheller was tested with machine capacity of 58-62 $\mathrm{kg} / \mathrm{h}$ with $98 \%$ shelling efficiency. The designed sheller is cost effective, as the cost of the sheller is Rs. 2,000/-.

\section{References}

Bahaley, S.G., Awate, A.U., \& Saharkar, S.V. (2012). Performance analysis of pedal powered multipurpose machine. International Journal of Engineering Research \& Technology, 1(5).

Danilo M. (1991). Maize Post-Harvest Operation: Chapter 2. Journal Food Agric. Org. United Nations (FAO), AGST. http://www.fao.org.

De, (2005). Energy use in crop production systems in India. Book No.CIAE/2005/2. Central Institute of Agricultural Engineering, Bhopal.

FAO. (1992). Maize in human nutrition. FAO Food and Nutrition Series, No.25. Food and Agriculture Organization, www.fao.org.

Food and Agricultural Organisation (FAO) (2005). Agricultural engineering in development shelling and shelling. http://www.fao.org//docrep/tos22e/tos2 2e07.htm.

http://ecoursesonline.iasri.res.in/mod/page/vie w.php?id=125404

Johnston, R. E. (1964). Statistical methods in foundry expts. AFS Trans. 72, 13-24.

Khurmi, R.S. \& Gupta, J.K. (2005). A textbook of machine design. Eurasia Publishing House (Pvt.) Ltd., New Delhi, India. 781-782.

Nkakini, S.O. (2007). Manually powered continuous flow maize sheller. Applied Energy, 1175-1186.

Nwakaire, J.N., Ugwuishiwu, B.O. and
Ohagwu, C.J. (2011). Design, Construction and performance analysis of a maize thesher for rural dweller. Nigerian Journal of Technology30:5054.

Oriaku, E.C., Agulanna, C.N., Nwannewuihe, H.U., Onwukwe, M.C. and Adiele, I.D. (2014). Design and performance evaluation of a maize de-cobbing and separating machine engineering. American Journal of Engineering Research. 03: 127-136.

Shelare S. D., Mali, P.K., Dr. Sakhale C. N. (2015). A Literature Review on Design and Development of Maize Thesher. International Journal of Pure and Applied Research in Engineering and Technology 3 (9), 9-14.

Singh, K.P., Pardeshi, I.L., Kumar, N., Srinivas, K. and Srivastava, A. K. (2008). Optimisation of machine parameters of a pedal-operated paddy thesher using RSM. Biosystems Engineering. (100):591-600.

Singh, S.P. (2010). Ergonomical interventions in developing hand operated maize dehusker-sheller for farm women. Ph. D. Thesis, CTAE Library, Maharana Pratap University of Agriculture and Technology, Udaipur, RAJASTHAN (INDIA).

Skromme, L. K. (1977). Progress report on twin rotor combine concept of rotary shelling and separation. ÀSAE/CIGR International Grain and Forage Harvesting Conference, Iowa State University, Ames, Iowa.

Tambari S., Gloria D.O., Diabi O.W., Victor Ayejah (2015). Technical Study on the Design and Construction of a Pedal Powered Hacksaw Cutting Machine. Journal of Mechanical and Civil Engineering. 04: 48-52.

Tiwari, P. S., Pandey, M. M., Gite, L. P. and Shivastava, A. K. (2010). Effect of operating speed and cob size on 
performance of a rotary maize sheller. International Journal of Research in Engineering and Technology. 47(2): 6871.

Wanjala, N.E. (2014). Design Of A Modified
Hand Operated Maize Sheller. University of Nairobi Department of Environmental and Biosystems Eng. 710.

\section{How to cite this article:}

Prajwal, R., V. Tanveer Mujtabha, V.N. Meghana and Prasanna Kumar, Er. 2021. Design and Development of Pedal Operated Maize Sheller for Small and Marginal Farmers. Int.J.Curr.Microbiol.App.Sci. 10(01): 1135-1144. doi: https://doi.org/10.20546/ijcmas.2021.1001.137 